Glare may arise through the presence of unduly bright lights in the direct field of vision or on the edge thereof, or through inconvenient direct reflection of light from shiny or polished material. Four requirements bearing on the above points are now suggested :-

(I) Every light source (except one of low brightness ${ }^{1}$ ) within a distance of roo $\mathrm{ft}$. from any person employed shall be so shaded from such person that no part of the filament, mantle, or flame is distinguishable through the shade, unless it be so placed that the angle between the line from the eye to an unshaded part of a source and a horizontal plane is not less than $20^{\circ}$, or in the case of any person employed at a distance of $6 \mathrm{ft}$. or less from the source not less than $30^{\circ}$.

(2) . . "Adequate means shall be taken, either by suitable placing or screening of the light sources, or by some other effective method, to prevent direct

1 I.e. with an intrinsic brilliance not exceeding 5 candles per sq. in. reflection of the light from a smooth or polished surface into the eyes of the worker."

(3) ... Adequate means shall be taken to prevent the formation of shadows which interfere with the safety or efficiency of any person employed.'

(4)..."No light sources which flicker or undergo abrupt changes in candle-power in such manner as to interfere with the safety or efficiency of any person employed shall be used for the illumination of a factory or workshop."

In view of the fact that extensive alterations may be occasioned by compliance with these requirements, it is further prescribed :-

(5) "That, as regards existing installations, a reasonable time limit should be given before the above requirements become operative.'

An appendix to the report contains extracts from codes adopted in various American States and recommendations made by the Illuminating Engineering Society in Germany.

\title{
The World's Wheat Supply.
}

THE statistics dealing with the wheat supply of the world are discussed by Sir James Wilson in an interesting and exhaustive paper entitled "The World's Wheat," contributed to the Journal of the Royal Statistical Society (vol. 84, part 3, May, 1921).

Having pointed out the varying accuracy of available statistics and explained the system of calculation adopted, the author gives the pre-war five-year average yields for all wheat countries, together with the exports and imports. For this period the world's vield was 107 million metric tons, of which $22.2 \mathrm{mil}$ lion metric tons-more than one-fifth of the wholewere produced by Russia. The net world exports amounted to 18.5 million metric tons, of which Russia again contributed the largest proportion, nearly onefourth of the whole; while of the net imports of I8.0 million metric tons Great Britain was the largest importer with 5.9 million metric tons, followed by Germany with $1 \cdot 9$ million metric tons. Naturally, these figures were all profoundly affected by war conditions. Statistics are not available for such important countries as Germanv, Austria, and Belgium among the importers, nor for Russia, Rumania, Hungary, and Bulgaria among the exporters, but for the twenty-one countries where figures have been published the average yield was 66.8 million metric tons during the war, compared with 63.1 million metric tons before the war. The importing countries on the average produced less than before the war, but they also imported less. Britain increased her average yield from $I \cdot 6$ to $I \cdot 9$ million metric tons and reduced her average net import from 5.9 to 5.2 million metric tons and her average consumption from 7.5 to 7.I million metric tons. The exporting countriesUnited States, Canada, and Argentina-all increased their yields considerably, and also their exports. Australia increased her yield, but her average export was much the sarne as the pre-war average, probably on account of the large loss of stored wheat by mice and weevil depredations. India's average yield during the war was practically the same as the pre-war average, but owing to the export restrictions enforced by the Government in the interests of the consumers her average net export fell from 13.5 million metric tons betore the war to 8.2 million metric tons during the war period.

With regard to the supplies of IgI9 and I920, excluding Kussia and Rumania (which in the pre-war average exported nearly one-third of the world's net exports) and India (export from which country was practically prohibited), the other exporting countries began the cereal year on August I, 1919, with about 6.r million metric tons of exportable supplies still in hand, while there was also a large quantity on its way to the importing countries. All the importing countries together in $1919^{-20}$ imported 18.2 million metric tons, which is about the pre-war average, and during that year the Argentine ar,d Australia got rid of their embarrassing surplus, while towards the end of the year the United States had practically a monopoly of export, and so obtained very high prices. Sir James Wilson estimates that for the current year ending July $3 \mathrm{I}$, $192 \mathrm{I}$, there will be 18.9 million metric tons available to meet the estimated demand of tons available to meet which will leave a sufficient, though not excessive, margin on the eve of the ripening of the new harvests in the northern hemisphere.

It is to the temporary advantage of consumers that there should be an excess of supply over demand, and to the temporary advantage of producers that the demand should exceed the supply; but for the world as a whole it is better that supply and demand should approximate. In the author's opinion, from the information available at the time, this condition should be reached as regards wheat on August I, I $2 \mathrm{r}$, and according to present prospects (excluding Russia, Rumania, and India) the harvest to be reaped after that date will yield sufficient to meet the world's probable demands. For the more distant future fears are sometimes expressed that the growth of the world's population, and especially of the number of wheat-eaters, will result in a permanent dearth of wheat, but it must be remembered that the great majority of mankind prefer grains other than wheat, and even the wheat-eaters substitute other grains without much sense of hardship.

With regard to wheat prices, in most European countries at the present day the high prices of wheat are largely due to the depreciation of the various paper currencies. The author discusses the different factors which will affect the wheat prices-rates of exchange, freight charges, etc.-and concludes that, so far as Britain is concerned, the price of wheat will be lowered if "the rate of exchange with the United States of America improves, and if Asia and South America continue to absorb gold at a great rate, and so help to reduce the prices of all commodities, measured in gold, all the world over." 